
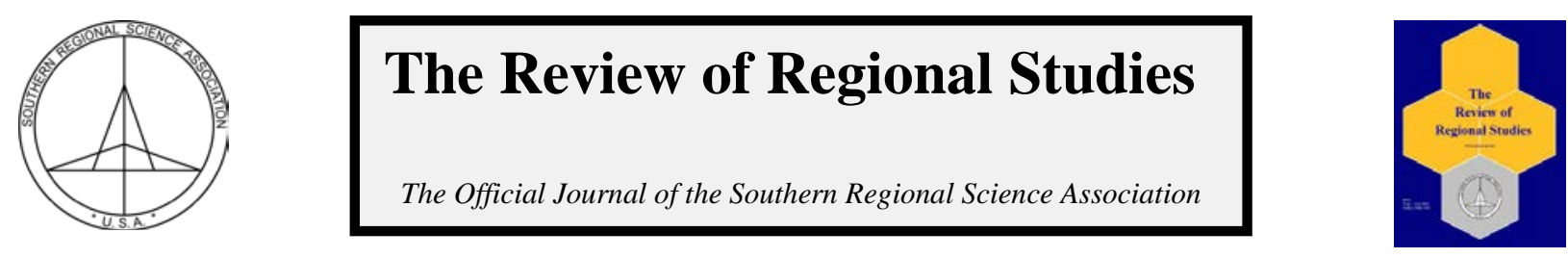

\title{
The Creative Class and Economic Development as Practiced in the Rural U.S. South: An Exploratory Survey of Economic Development Professionals
}

\author{
William Hatcher ${ }^{\mathrm{a}}$, Matt Oyer ${ }^{\mathrm{b}}$, and Roberto Gallardo ${ }^{\mathrm{c}}$ \\ ${ }^{a}$ Department of Government, Eastern Kentucky University, USA \\ ${ }^{b}$ Community Development Planner, Heart of Georgia Regional Commission, USA \\ 'Southern Rural Development Center, Mississippi State University, USA
}

\begin{abstract}
The research administers an exploratory survey to local economic developers in the state of Kentucky to examine opinion regarding the creative class. We hypothesize that Kentucky officials, especially the ones from the rural areas of the state, will be skeptical of the creative class theory of economic development. However, analysis shows half of the sampled economic developers to be supportive of the creative class, and rural developers are just as likely as urban ones to support the theory.
\end{abstract}

Keywords: creative class, rural economic developers, local economic development

JEL Codes: O10, R10, R58

\section{INTRODUCTION}

There is often a gap between economic development scholarship and practice (CurridHalkett and Stolarick, 2011). This divide appears to be even more pronounced when it comes to the creative class theory of development. Scholars tend to be critical of the theory (Peck, 2005; Boschma and Fritsch, 2009; Donegan et al., 2008), but practitioners are often positive. The support for the theory among practicing officials can be seen in the number of creative cities initiatives throughout the nation (Currid-Halkett and Stolarick, 2011). The collection of economic development literature referred to as the "creative class" (Florida, 2003a, 2003b) has been mostly urban-centered and has not examined the opinion of practitioners in a rural setting. Given the divergence of opinion on the creative class and the lack of research on opinion among rural practitioners, we seek to understand: How does the creative class theory apply in a state comprised mostly of small cities with service and manufacturing economies? What economic policies do developers in this state view as effective? In this paper we survey economic development officials in Kentucky to understand their opinions of the creative class theory and more broadly to describe the economic development policies of their communities.

In The Rise of the Creative Class, Richard Florida (2003a) argues that communities with more individuals involved in the arts and other creative professions (such as teachers, architects,

Hatcher is an Assistant Professor in the Department of Government at Eastern Kentucky University, 521 Lancaster Avenue, Richmond, Kentucky 40475; Oyer is a Community Development Planner at the Heart of Georgia Regional Commission; Gallardo is an Assistant Extension Professor at the Southern Rural Development Center, Mississippi State University. Corresponding Author: W. Hatcher E-mail: william.hatcher@eku.edu.

(C) Southern Regional Science Association 2012.

ISSN 1553-0892, 0048-749X (online)

www.srsa.org/rrs 
computer engineers, etc.) are more likely to be economically prosperous, compared to communities with more traditional labor forces. The creativity associated with art-related professions leads to more innovation and more productive economies in these communities. Therefore, based on this model of development, local governments should enact developmentrelated policies fostering their creative class. Communities foster creativity by funding arts and culture development, encouraging racial and social tolerance, and promoting technological advancement. To Florida, these nurturing development policies are more effective than traditional development policies, such as attracting business by offering tax incentives. Based on empirical research of economic development throughout the United States, Florida's model holds that the creative classes are attracted to cities that value technology, cultivate artistic talent, and practice tolerance. Florida's theory appears to be an urban-centered one. Many rural communities throughout the nation may lack the attributes of tolerance, talent, and technology. Given this, what role does Florida's theory play in rural communities? Economic scholarship and theory has dedicated much attention to the creative class (Currid-Halkett and Stolarick, 2011). Except for the work of a few scholars (e.g., McGranahan and Wojan, 2007a, 2007b; Rickman and Rickman, 2011), the literature overlooks the need to develop workable models of creativity for the nation's rural communities. To determine the usefulness of the creative-class theory for rural communities, the opinions of rural developers need to be assessed.

FIGURE 1. Kentucky Employment by Industry, 2009

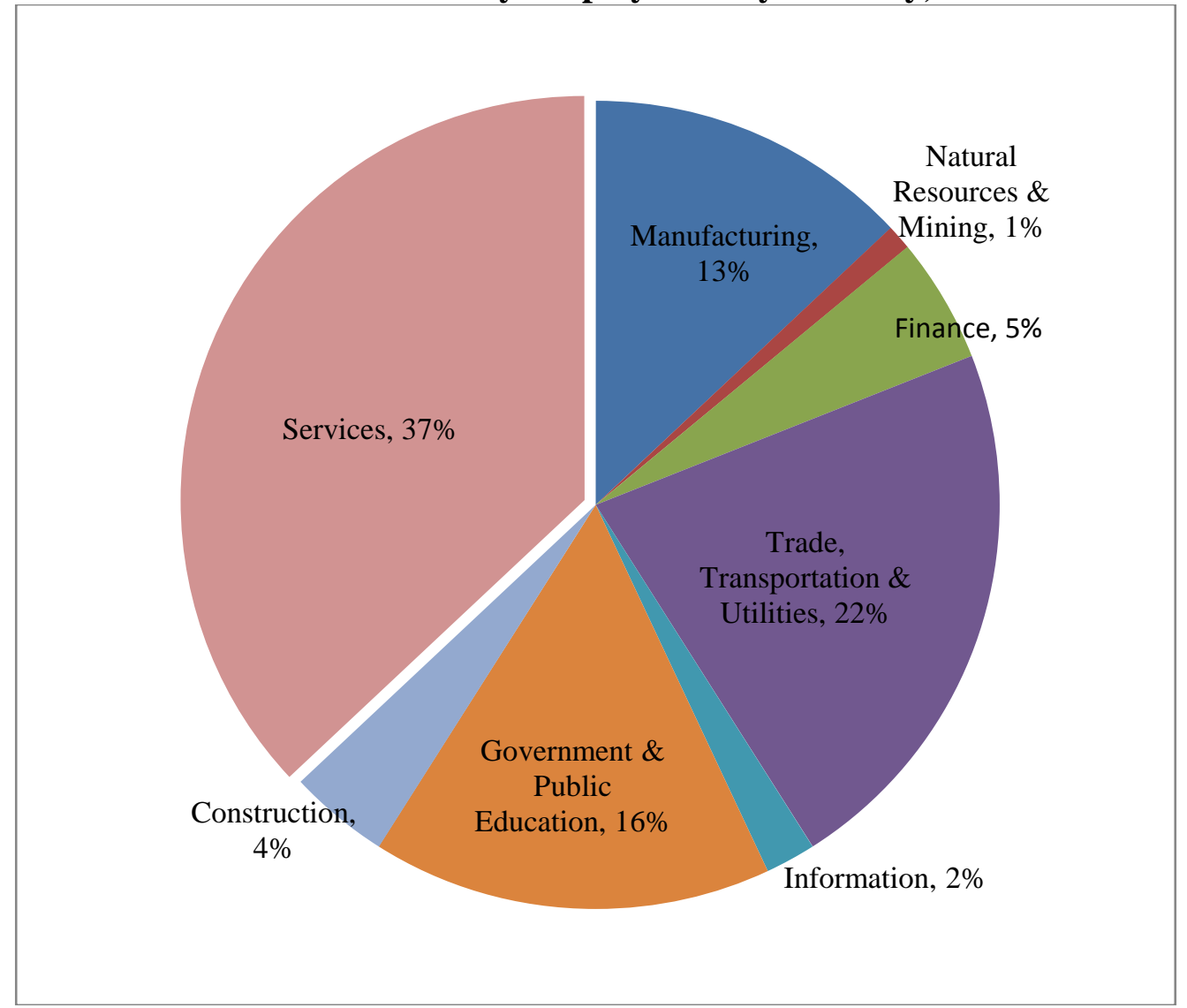

Source: Workforce Kentucky. (n.d.). Industry Data Graphs. Retrieved September 5, 2011, from http://www.workforcekentucky.ky.gov/?PAGEID=3\&SUBID=117 
FIGURE 2. Kentucky Employment by Class and Core-based Typology, 2010

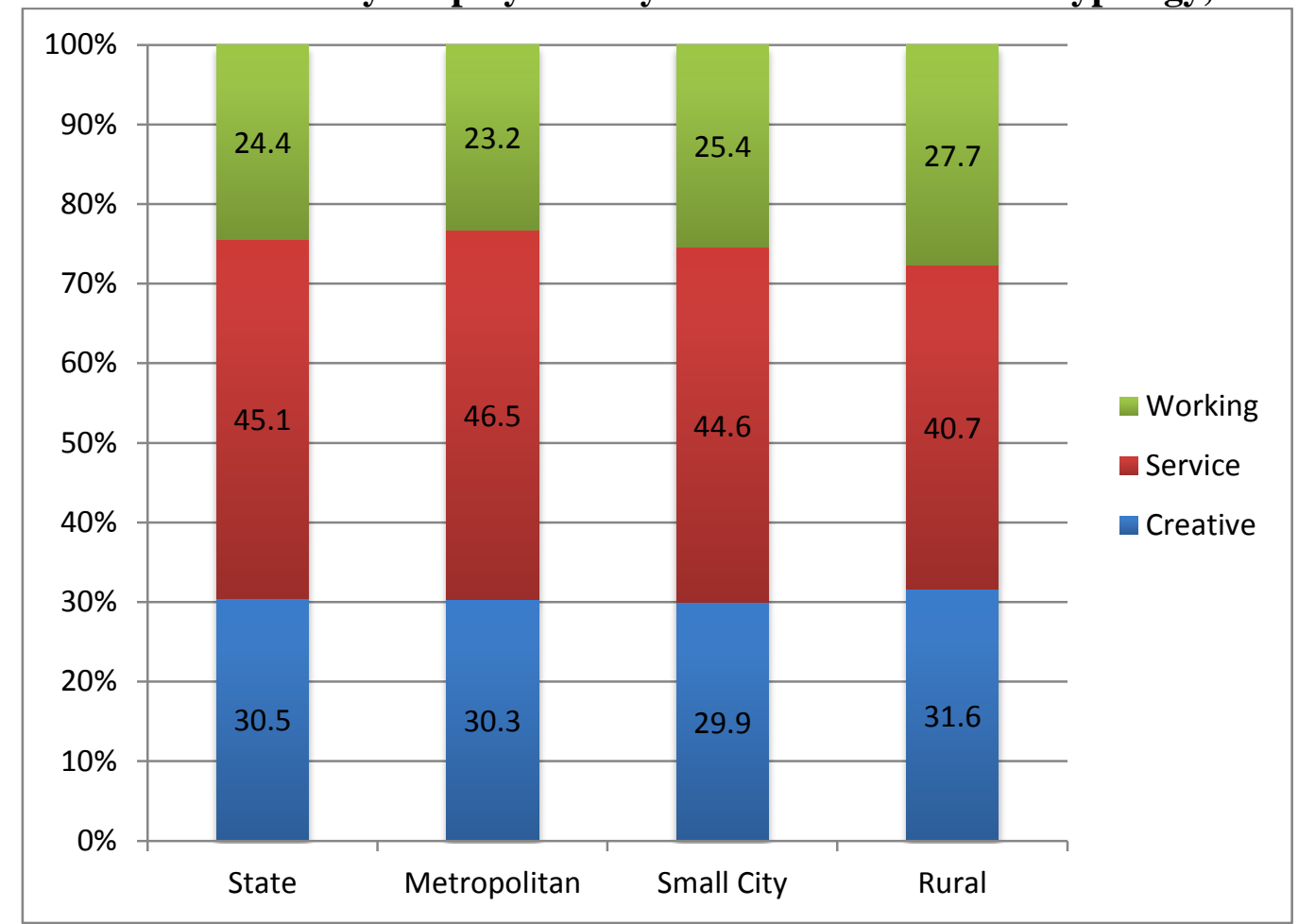

Source: Economic Modeling Specialists, Inc. - Complete Employment 2011.3

Note: Employment does not include Farming, Fishing, and Forestry and Military Occupations

Kentucky is an ideal case to examine the opinion of rural developers in a state with a strong service-class economy. As shown in Figure 1, a plurality of the state's jobs is in service industries. The state is also a rural one. Over 60 percent of the state's municipalities have a population of 2,000 people or less (Kentucky League of Cities, 2010). Most of the economic development directors in our sample represent countywide organizations serving rural areas.

Further, a better understanding of the perception of rural economic developers regarding the creative class strategy is crucial since according to data from Economic Modeling Specialists, Inc., ${ }^{1} 31.6$ percent of total employment in rural ${ }^{2}$ counties worked in creative occupations in 2010. This percentage is higher than the state overall (30.5 percent), metropolitan counties (30.3 percent) and micropolitan (small city) counties (29.9 percent).

Similarly, Table 1 shows that jobs in creative occupations experienced a 5.7 percent increase between 2005 and 2010 in the state overall compared to a job increase of only 0.8 percent in service occupations and a job decline of 11.2 percent in working occupations. ${ }^{3}$ Although metropolitan counties experienced the highest job increase in creative occupations between 2005 and 2010, small city and rural counties also experienced an increase.

\footnotetext{
${ }^{1}$ Appendix 1 explains the Economic Modeling Specialists data and the types of jobs in each of these categories.

2 The 2003 Core-based typology developed by the Office of Management and Budget was utilized to group counties into metropolitan, small cities (micropolitan), and rural (noncore). Metropolitan counties include those with an urbanized area of 50,000 or more and outlying counties that are economically tied to the central counties (i.e. 25 percent of workers living in the outlying counties but working in the urbanized area; micropolitan counties include those with an urbanized area between 10,000 and 49,999 as well as those counties where at least 25 percent of their workforce commutes to an urban center in a neighboring county; noncore counties include those that have no urbanized area or town of at least 10,000 people.

${ }^{3}$ For a list of occupations used for the creative, service, and working classes please refer to Appendix A.
} 
TABLE 1. Jobs Percent Change in Creative, Service, and Working Occupations, 2005-2010

\begin{tabular}{lccl}
\hline \hline & Creative & Service & Working \\
\hline State & 5.7 & 0.8 & -11.2 \\
Metropolitan & 7.0 & 1.5 & -11.5 \\
Small City & 4.0 & -0.4 & -11.4 \\
Rural & 2.8 & -0.6 & -9.9 \\
\hline \hline
\end{tabular}

Source: Economic Modeling Specialists, Inc. - Complete Employment 2011.3

The State of Kentucky has certain economic growth characteristics that would benefit from a creative class approach to development. These features can be found in the state's urban communities, especially Lexington and Covington, and also a number of rural communities. Florida's Three T's are especially clear in Lexington. The city has a highly educated workforce. According to the U.S. Census, approximately 40 percent of the population 25 or older has at least a bachelor's degree with 16 percent holding an advanced degree (Commerce Lexington, n.d.). Due to its highly skilled workforce, Forbes ranked Lexington fourth in the magazine's annual "Best Places for Business" survey (Commerce Lexington, n.d.). Louisville was also highly ranked (number 14). Lexington's economy enjoys the presence of the University of Kentucky and its research centers. Lexington also appears to be a tolerant community. For instance, the city has a strong gay community, which is demonstrated by the fact that the current Mayor, Jim Gray, is an openly gay man.

Covington, Kentucky, has implemented a number of creative class initiatives. For one, the city provides incentives for artisans to relocate to the city's arts district. ${ }^{4}$ The city has structured large parts of its economic development strategy around fostering the arts in the community. Currid-Halkett and Stolarick (2011, p 150) found that an agency in the city "went as far as to package and distribute creative gift boxes as part of its development scheme."

The rural parts of the state may not have all of Florida's Three T's, but these communities hold a wealth of cultural and outdoor amenities. For instance, the small community of Greensburg, Kentucky, with assistance from the Kentucky League of Cities, has recently undergone a community development improvement plan focused on taking advantage of the community's natural and cultural resources (Kentucky League of Cities, n.d.). The rural community's political leadership supports an ambitious plan to take advantage of the area's outdoor amenities. These initiatives seek to build walking and hiking trails around the local Green River along with a regional park connected to the nearby, already established Green River State Park. These outdoor amenities are part of a marketing strategy to grow and to retain the community's creative class. Greensburg is trying to engage young professionals in these development initiatives. This is a difficult task, but there are other examples in rural Kentucky for Greensburg to follow. For instance, Inez, the location of Lyndon Johnson's famous photo-op at the start of the Great Society, has successfully engaged creative professions-i.e., lawyers, pharmacists, teachers, and engineers - in the development process for the town (Long, 2012).

Overall, the state practices traditional economic development, emphasizing tax breaks and attraction-based policies. And even though Kentucky holds a wealth of natural and cultural resources, we hypothesize that economic developers in Kentucky will be skeptical of the creative

\footnotetext{
${ }^{4}$ For more information, see: http://www.covingtonarts.com/about.shtml
} 
class theory. This view is based on the state's traditional marketing approach to development and our interpretation of the current scholarly literature.

\section{LITERATURE REVIEW}

Creativity has been a consistent focus among students of economic development and urban planning. Jane Jacobs (1961) wrote of the decline in urban communities and the loss of innovation due to the rationalist policies of urban renewal. To Jacobs, communities such as Greenwich Village in New York City are innovative by having people who interacted on a regular basis in creative endeavors. Yet, many traditional economic policies have focused on attracting companies to a region. Florida's ideas call for policies that seek to attract creative individuals and to foster current creative capital among a community's current population. Historically, economic development practice has focused on the importance of place and attracting businesses through place-based tools, such as property tax abatements. These policies are often exogenous.

Over recent decades, economic development has started to focus more on people-based policies, in particular the features of a region's labor force (Mathur, 1999). This inward approach (endogenous policies) has been advocated by theorists focusing on human capital (Romer, 1986 \& 1990; Mathur, 1999) and social capital (Putnam, 2000; Putnam and Feldstein, 2003). For example, Putnam and Feldstein (2003) argue that successful local economic development is based on an understanding of the social ties within communities or social capital. By moving toward more people-based policies of development, communities have sought to foster their existing businesses through better networking and outreach programs and to improve their labor forces through policies that nurture the labor force, such as job training. These policies, as noted, are often referred to as endogenous ones. Creativity in economic development often is associated with endogenous theories. These approaches focus on strengthening human capital in a region (Donegan et. al, 2008). Research shows that communities with endogenous policies have successful development outcomes (Donegan et. al, 2008; Mathur, 1999).

Florida extends this people-based focus by calling for efforts to increase a region's creative capital. It is a model that takes into account both people and place, or as Florida describes it, "the geography of creativity." This geography of creativity is creating a "spiky world," not a "flat world," where communities with creativity thrive. We are not interested in debating Florida's statistical analysis, which has already been critiqued in the literature (McGranahan and Wojan, 2007; Pratt, 2008). Nonetheless, a brief overview of Florida's measures is needed to understand how the creative class affects developers' opinions and policies. According to Florida (2003b), his thesis differs from standard labor capital theories by focusing on technology, talent, and tolerance. As noted, he operationalizes these concepts into an index to rank the metropolitan areas in the United States based on their creativity. Tolerance is defined "as openness, inclusiveness, and diversity to all ethnicities, races, and walks of life" (p. 10). He operationalizes these values by using the Gay and Bohemian index. This measure is comprised of the number of gay and lesbian households and the number of individuals employed in the arts. Talent is the possession of a Bachelor's degree or higher-a definition often used by labor capital theorists. Lastly, technology is defined as having "both innovation and hightechnology concentrations in a region” (p. 10). Florida and his associates combine talent and technology indicators to develop the Talent index. In the U.S., these measures in Florida's 
statistical analyses show that the creative centers are, to name a few, San Francisco, Seattle, Boston, Chicago, Minneapolis, Denver, and Boulder.

In Who's Your City? (2009), Florida extends his work through the use of migration data to show how creative cities are attracting new productive workers, while the noncreative cities are stalling or losing population. The economic downtown starting in 2007 led Florida (2011) to adapt his creative class for the so-called new norm of the United States economy. In this work, he refers to a period of “creative destruction" (Schumpeter, 1962) akin to the Great Depression in which there is an opportunity to rebuild our cities in line with his creative-class ideas of focusing on technology, education, infrastructure, and amenities.

Florida's creative-capital ideas have been attacked from numerous angles, but there have been few empirical studies in the literature (Donegan, et al, 2008). Among the argumentative essays and empirical findings, the following themes emerge in the critical literature. First, scholars argue that there is no clear definition of the creative class and the model is just a repackaging of old ideas. For instance, Pratt (2008) argues that the creative class is not operationalized to allow for comparison among communities. Others, such as Rausch and Negrey (2006), argue that the creative-class argument is not different from the people-based policies within the human capital model of economic development. Florida merely uses different measures, but the focus is the same. Additionally, Sands and Reese (2008) argue that a large degree of diversity in a city does not necessarily mean that the city is tolerant. More diversity may lead to more conflict among groups.

Second, the efficacy of the creative-class thesis as a model of development has been challenged based on empirical research. For one, Donegan et al. (2008) hold that there is no empirical evidence supporting Florida's claim that creative indicators are related to economic growth. However, an analysis of European development by Boschma and Fritsch (2009) shows that communities with a strong creative class produced significant growth and new business creation. These are some of the few empirical studies examining the creative class.

Lastly, critics have contended that the creative-class thesis is elitist in how it ignores inequality in communities and the working poor (Peck, 2005). The creative-capital model is only designed for urban areas with contractions of middle-class professions and artists. Florida is selling "cool-cities" at the expense of traditional manufacturing communities and service-based economies.

Economic development scholars have attempted to rework the creative class. Schoales (2006) enlarged the creative class to include professions, such as clothing and jewelry (p. 175). Conversely, McGranahan and Wojan (2007a) found strong empirical evidence for growth related to quality of life improvements in urban and rural regions by restructuring Florida's creativeclass measures to remove professions that they viewed as having "low creativity requirements" and ones "involved primarily in economic reproduction" (p. 197). Rickman and Rickman (2011) also found strong evidence that amenities and quality-of-life issues may be driving migration to rural areas. The critiques of the creative-class focus on how the theory supposedly only benefits urban areas, but recent research shows that rural areas can benefit from the creative class ideas.

According to McGranahan and Wojan (2007b), nonmetropolitan counties tend to perform very well on many creative-class indicators, seemingly causing rises in economic productivity in these communities. For example, from 1990-2004, nonmetropolitan counties with concentration of creative-class jobs had high rates of patent formation and manufacturing technology. The 
authors also note that the rural areas, especially rural college communities, have a surprising number of creative-class citizens. In another study, Brock (2009) found rural pockets of the creative class in Canada. Perhaps these findings explain why a number of nonmetropolitan counties are becoming "spikes" in the creative-class landscape. As discussed later, these findings concerning rural regions is significant to our focus on the opinion held by developers in Kentucky.

The creative class has been examined from a number of angles, but few studies have examined the opinion of the creative class held by economic development practitioners. The only study found in the literature was one conducted in Europe. Bontje and Musterd (2009) interviewed practitioners in seven European city-regions regarding the creative class and economic development. The authors found diversity of opinion regarding the theory with some experts supportive of it and others critical of the approach. This research was done in an urban setting, however. There are no studies in the literature that examine opinion in a setting that is predominately rural.

Since there are few studies examining the opinion of practitioners regarding the creative class, we examined the general literature on what economic developers view as effective development policies. Surprisingly, there is little research in the literature examining the individual perceptions of the roles played by economic developers. Levy's (1990) work examining the work perceptions of developers is one of the most robust contributions in the literature. The author surveyed economic development directors, and found that most viewed their daily work as sales activities or marketing of a community rather than rational model activities that seek to "alter the physical, financial, or demographic realities of the community" (p. 154). The creative-class approach to development does not fit nicely into either the sales activities approach or the rational model activities. Perhaps it is best to view the creative class theory as a combination of these two models used by Levy. For example, creative class developers try to alter their communities by trying to expand arts-related opportunities. On the other hand, creative class developers certainly seek to market the cultural capital of their communities.

This confusion over the roles of economic developers can be linked to the lack of understanding in the literature of the opinion held by practitioners. Currid-Halkett and Stolarick (2011) find a significant divide between scholarship and practice. From their study, it is clear that urban practitioners are mostly supportive of the creative class ideas, even if scholars are often critical. Given the lack of research on the opinion of rural developers regarding the creative class practices, we contribute to the literature by conducting an exploratory inquiry into the opinion of local economic developers in Kentucky.

\section{RESEARCH METHOD}

We administered a web-based exploratory survey to the directors of local economic development organizations in Kentucky. Most of these organizations are countywide. The contact information for these officials was obtained from the Kentucky Cabinet for Economic Development. Three waves of the survey were sent out (August 10-September 5, 2011), with an overall response rate of 51 percent $(n=52)$. According to Porter and Whitcomb (2007), the response rate is comparable to, if not better, than many studies surveying officials through webbased tools. The survey instrument includes the following types of questions: factual questions seeking to determine if officials are familiar with creative class ideas for economic development; 
attitudinal questions regarding the efficacy of the creative class ideas; attitudinal questions asking respondents to rank examples of local economic development policies based on their perceived efficacy; attitudinal questions asking respondents to rank the best actions of their organizations; and factual questions asking respondents the demographic and economic characteristics of their communities.

The breakdown of the sample's demographics and other characteristics are as follows. The state's economic development directors are commonly male (77 percent, $n=52$ ), over the age of 60 (42 percent, $n=52$ ), and holders of at least a Bachelor's degree (77 percent, $n=52$ ). By a small margin, a plurality of the officials consider their work to be public administration (47 percent, $n=51$ ) instead of business administration. A majority of the officials have not completed any type of economic development certification program (54 percent, $n=50$ ). Most of the state's counties are represented, leading to a balanced geographical sample. Only a few of the respondents consider their communities as urban ones (12 percent, $n=52)$.

\section{RESEARCH HYPOTHESES}

This study is an exploratory one, interested in learning more about the opinions of rural economic developers regarding economic development practices, in particular ones promoted by the creative class theory. However, to guide the research, we developed the following hypotheses based on our interpretation of the literature and other a priori expectations.

First, in general, given the economic nature of Kentucky, we hypothesize that economic developers are skeptical of the creative-class theory. The state's overall economic development climate is one that leans toward marketing strategies. For instance, the state made national news in 2011 by offering large tax breaks to a religious-based park. As detailed, the state's economy is comprised of a plurality of service-based jobs. We suspect that this market-centered culture trickles down to developers at the local level in the state.

$H_{1}=$ Economic developers in Kentucky hold a negative opinion regarding the efficacy of the creative-class theory.

Within this broad hypothesis, we were interested in exploring any differences of opinion regarding efficacy among the developers. Kentucky, as discussed, is a largely rural state with a traditional marketing approach to economic development. Given this, we hypothesize that economic developers in rural areas are likely to be more skeptical of the creative class, compared to their urban counterparts. Critics of the creative-class theory have attacked it for not providing a normative model for rural economic development. Additionally, the theory's focus on technology and tolerance are often at odds with the economic characteristics of rural communities in a state like Kentucky. Given this, we formulated hypothesis two to examine the differences between urban and rural developers.

$\mathrm{H}_{2}=$ Economic developers in the State of Kentucky who identify their communities as rural are more skeptical of the creative-class theory, compared to their urban counterparts.

Economic theory and practice traditionally has placed a large focus on marketing strategies (Levy, 1990). Kentucky's overall development policies appear to do the same. It can be asserted that developers who identify as doing work that is considered business administration may be more skeptical of the creative class. This identification may be based on the training of individuals who identify their work as business administration, compared to public administration. Developers who identify as public administrators may take a more creative-class-

(c) Southern Regional Science Association 2012. 
based approach to their jobs. Given their training and the state's policy climate, we hypothesize that economic developers identifying as business administrators are likely to be more skeptical of the creative class than are developers identifying themselves as public administrators.

$H_{3}=$ Economic developers in the State of Kentucky who identify themselves as business administrators are more skeptical of creative-class theory than are developers who identify themselves as public administrators.

The remaining hypotheses seek to investigate the effects of the demographic differences of age, gender, and education among the developers.

$\mathrm{H}_{4}=$ Older economic developers in the State of Kentucky will be more skeptical of the creativeclass theory, compared to younger economic developers.

$\mathrm{H}_{5}=$ In the State of Kentucky, gender affects the opinion of economic developers with respect to creative-class theory.

$H_{6}=$ More highly educated economic developers in the State of Kentucky are more likely to support the creative-class theory, compared to economic developers with lower levels of education.

In the following section, we test these hypotheses through contingency table analysis and factor analysis.

\section{ANALYSIS AND FINDINGS}

The analysis seeks to understand the respondents' opinion on the efficacy of development policies in their communities and the creative class theory. We found that the respondents held mixed views regarding the efficacy of the creative class theory in their communities. We arrived at this conclusion by utilizing descriptive statistics, bivariate contingency table analysis, and factor analysis.

\subsection{Efficacy of Development Policies}

We examined the developers' opinions regarding the efficacy of development policies to test our general hypothesis that Kentucky developers will be skeptical of the creative class theory. We asked the respondents a series of questions regarding the effectiveness of common economic development policies. These policies range from more traditional exogenous ones, such as attracting new business, to more creative-based ones, such as fostering cultural capital and building amenities. We divided these questions into two sections: their opinion on the proper role of their development organizations and their opinion on the efficacy of policies. We constructed two types of policies to examine officials' opinions on the creative class: traditional ones (attraction of new business, retention of current ones, and workforce training) and creative ones (promotion of arts and culture, website promotion, and tourism). We also made a distinction between exogenous policies (i.e., attraction of businesses) and endogenous policies (i.e., improvement of current development assets).

Hypothesis $H_{1}$ that Kentucky developers are skeptical of the creative class theory was not confirmed. In this hypothesis, we assumed that the level of support for the creative class among economic developers in Kentucky would be little to none. However, we found that 50 percent of our sample answered in the affirmative when asked if they think the creative-class ideas improve development within communities. This surprising support among developers in a rural state is 
one of the most significant finding in our study. Given the small size of our sample, this finding should be viewed with caution. The sample is small because the study's overall population (i.e., the heads of local, countywide economic development organizations) is relatively small ( $n=$ 102). Based on the sample size, the finding that 50 percent of the developers support the creative class has a confidence interval of $+/-13$ percent. The large margin of error is certainly a limitation of our research. This is why we view this study as an exploratory one. But the finding is still important because we hypothesized little to no support among Kentucky developers for the creative class ideas. Overall, the research holds value because it examines a neglected area of research-i.e., the opinion of rural developers regarding the creative class.

Even though half of our respondents supported the creative class, when asked about the efficacy of policies for their organizations, Kentucky developers still appear to favor traditional approaches. For instance, 49 percent $(n=51)$ of respondents strongly agree that economic development organizations should focus on attracting new businesses, 53 percent $(n=51)$ strongly agree that their agencies should improve the current workforce, and 80 percent $(n=51)$ strongly agree that their agencies should seek to retain current businesses.

Table 2 displays the average answers from the respondents on the five-point scale regarding effective policies for their organizations. As can be seen, the two related to the creative class theory are ranked the lowest with most respondents slightly agreeing or being neutral (In Table 2 see, Economic development agencies should focus on tourism development and Economic development agencies should focus on attracting new business by marketing the art and cultural opportunities in their communities).

TABLE 2. Efficacy of Policies for Economic Development Agencies

\begin{tabular}{|c|c|}
\hline \multicolumn{2}{|c|}{$\begin{array}{l}\text { Please rank the following statements based on your level of agreement with the effectiveness o } \\
\text { these tasks as strongly disagree, disagree, neutral, agree, or strongly agree }\end{array}$} \\
\hline Economic development policy & Average on a scale of $1-5$ \\
\hline $\begin{array}{l}\text { Economic development agencies should focus on } \\
\text { attracting new businesses. }\end{array}$ & 4.4 \\
\hline $\begin{array}{l}\text { Economic development agencies should focus on } \\
\text { improving the current workforce in their communities. }\end{array}$ & 4.5 \\
\hline $\begin{array}{l}\text { Economic development agencies should focus on } \\
\text { retention of current businesses. }\end{array}$ & 4.7 \\
\hline $\begin{array}{l}\text { Economic development agencies should focus on } \\
\text { marketing a community's workforce. }\end{array}$ & 4.3 \\
\hline $\begin{array}{l}\text { Economic development agencies should focus on tourism } \\
\text { development. }\end{array}$ & 3.6 \\
\hline $\begin{array}{l}\text { Economic development agencies should focus on } \\
\text { attracting new business by marketing the art and } \\
\text { cultural opportunities in their communities. }\end{array}$ & 3.6 \\
\hline $\begin{array}{l}\text { Economic development agencies should advocate for } \\
\text { improvements to the infrastructure (roadways, Internet } \\
\text { access, water service, sewerage service, etc.) of their } \\
\text { communities. }\end{array}$ & 4.6 \\
\hline
\end{tabular}




\section{TABLE 3. Efficacy of Policies for Economic Development in Respondents' Community}

\begin{tabular}{|c|c|}
\hline \multicolumn{2}{|c|}{$\begin{array}{l}\text { Next, you will be asked to rank specific economic development tools based on their effectiveness at } \\
\text { improving your community's economy. Rank the following economic development tools based on their } \\
\text { effectiveness from "not effective at all" to "very effective" at improving your community's economy }\end{array}$} \\
\hline Economic development policy & Average on a scale of $1-4$ \\
\hline $\begin{array}{l}\text { Tax incentives, such as property tax abatement or lowering of } \\
\text { the occupational tax }\end{array}$ & 2.8 \\
\hline Workforce training, such as adult vocational training & 2.9 \\
\hline Marketing tourist attractions, such as having a tourism office & 2.4 \\
\hline Website promotions & 2.9 \\
\hline Increasing your community's art and cultural opportunities & 2.3 \\
\hline
\end{tabular}

When asked their opinions on specific programs within traditional and creative policies, the support weakens. Most developers still support workforce training with a 2.9 average on the following four point scale: not effective at all, somewhat effective, effective, and very effective. Interestingly, website promotion also was supported strongly. We viewed website promotion as being a tool to sell a community's amenities. The officials, based on their responses, may think of website promotion as selling their communities to new industries. The clear creative class policy, increasing your community's art and culture opportunities, received the lowest support from the developers. Based on Tables 2 and 3, developers in Kentucky appear to be lukewarm about the Florida's ideas. Next, we attempt to see what factors may be influencing this lackluster view of the model.

\subsection{Contingency Table Analysis}

Bivariate contingency-table analysis was used to explore the factors driving opinion among the developers. We used Goodman and Kruskal's Gamma $(\gamma)$ as a measure of descriptive strength to test Hypotheses 2-6. Gamma is a commonly used measure of association to determine the strength and direction between two variables in ordinal-by-ordinal tables. Gamma is also an appropriate measure for tables that have a nominal dichotomous variable. The value of Gamma ranges from $+/-0$ to $+/-1$. The closer the value is to one $(+/-)$, the stronger the relationship between the two variables. The sign signifies the direction of the relationship in the contingency table. ${ }^{5}$ Because of its common usage in contingency-table analysis, we used Gamma as a measure of association to test the research's hypotheses. To illustrate the mechanics of Gamma, we explain the measure's formula below (Giventer, 2008, p. 229):

(1) $\gamma=\frac{\text { number of concordant pairs-number of discordant pairs }}{\text { number of concordant pairs+number of discordant pairs }}$

Gamma and similar measures of association "compare the ordinal ranking of each case against that of every other case” in a contingency table (Giventer, 2008, p. 204). Gamma does this by

\footnotetext{
${ }^{5}$ Gamma is especially sensitive to corner cases (i.e., cells that have very small values) in a contingency table. When a table has a corner case, another measure of association should be employed .We planned to uses Kendall's Tau in such a situation, but none of our contingency tables had corner cells.
}

(c) Southern Regional Science Association 2012. 
comparing the concordant pairs and the discordant pairs in a contingency table. Concordant pairs are ranked in the same order for both variables in the table, and discordant pairs are ranked in a different order for both variables in the table. Ties are not included in the formula. Giventer (p. 204-205) explains how the total numbers of concordant and discordant pairs are calculated:

The total number of concordant pairs in the whole crosstabulation is sum of the products of the frequency in each cell multiplied by the frequencies in the cells located below and to the right... The total number of discordant pairs in the whole crosstabulation is the sum of the products of the frequency in each cell multiplied by the frequencies in the cells located below and to the left.

By dividing the difference between the concordant and discordant pairs by the sum of the concordant and discordant pairs, we measure the relationship between the two variables.

To test the study's general hypotheses, we examined the relationships between key questions. Table 4 displays the study's hypotheses and our empirical decisions regarding each one. This paper is concerned with opinion in rural areas, and our sample heavily self identifies as being developers in rural areas. Only six developers identified their communities as urban (12 percent, $n=52$ ). Given the debate over the usefulness of Florida's theory in rural areas, we assumed that rural developers in a state with a traditional marketing approach to economic development would be critical of the creative class, and their urban counterparts would be more

TABLE 4. The Findings on the Research's Hypotheses

\begin{tabular}{|c|c|c|}
\hline & Decision & Evidence \\
\hline $\begin{array}{l}H_{1}=\text { Economic developers in Kentucky will hold a negative } \\
\text { opinion regarding the efficacy of the creative class theory. }\end{array}$ & $\begin{array}{l}\text { Accept the } \\
\text { null }\end{array}$ & $\begin{array}{l}50 \% \text { of respondents held a favorable } \\
\text { opinion of the creative class and factor } \\
\text { analysis showed multiple groupings of } \\
\text { opinion }^{6}\end{array}$ \\
\hline $\begin{array}{l}\mathrm{H}_{2}=\text { Economic developers in the state of Kentucky who identify } \\
\text { their communities as rural will be more skeptical of the creative } \\
\text { class theory, compared to their urban counterparts. }\end{array}$ & $\begin{array}{l}\text { Accept the } \\
\text { null }\end{array}$ & Gamma $=.15(p>.05)^{7}$ \\
\hline $\begin{array}{l}H_{3}=\text { Economic developers in the state of Kentucky who identify } \\
\text { as business administrators will be more skeptical of the creative } \\
\text { class than developers who identify as public administrators. }\end{array}$ & $\begin{array}{l}\text { Accept the } \\
\text { null }\end{array}$ & Gamma $=.39(\mathrm{p}>.05)$ \\
\hline $\begin{array}{l}\mathrm{H}_{4}=\text { Older economic developers in the state of Kentucky will be } \\
\text { more skeptical of the creative class, compared to younger } \\
\text { economic developers. }\end{array}$ & $\begin{array}{l}\text { Accept the } \\
\text { null }\end{array}$ & Gamma $=-.37(p>.05)$ \\
\hline $\begin{array}{l}H_{5}=\text { The gender of economic developers in the state of Kentucky } \\
\text { will affect their opinion regarding the creative class theory. }\end{array}$ & $\begin{array}{l}\text { Accept the } \\
\text { null }\end{array}$ & Gamma $=.65(p>.05)$ \\
\hline $\begin{array}{l}H_{6}=\text { Economic developers in the state of Kentucky with higher } \\
\text { levels of education are more likely to support the creative class } \\
\text { theory, compared to economic developers with lower levels of } \\
\text { education. }\end{array}$ & $\begin{array}{l}\text { Accept the } \\
\text { null }\end{array}$ & Gamma $=.13(p>.05)$ \\
\hline
\end{tabular}

\footnotetext{
${ }^{6}$ For the analysis, see the descriptive statistic section and the factor analysis section.

${ }^{7}$ For the analysis for $\mathrm{H}_{2}-H_{6}$, see the contingency table analysis section.
} 
supportive. However, on examining $\mathrm{H}_{2}$, we found no statistically significant difference between rural and urban developers (Gamma $=.15 ; p>.05 ; n=45) .{ }^{8}$ Therefore, we accepted the null and found that rural developers were just as likely as urban ones to support (or not support) the creative class.

Next, to examine $H_{3}$, we asked respondents whether they view their work and background as public administration or business administration. It can be assumed that developers who view their work, as public administration may be more supportive of Florida's ideas due to the identification of their careers as public service, compared to developer identifying as being in business administration. We found no statistically significant relationship between the developer's perception of their work as public or business administration and their opinion on the efficacy of the creative class in their communities (Gamma $=.39 ; p>.05 ; n=$ 40). ${ }^{9}$ There is also no relationship between field perception and opinion on promoting cultural opportunities (Gamma $=.32 ; p>.05 ; n=40){ }^{10}$

Lastly, we examine the demographics and educational differences among the study's sample $\left(H_{4}-H_{6}\right)$. The gender of the developer appears to be having some effect on opinion of the creative class. But while the Gamma is .65, the probability falls barely short of statistically significant $(p=.051){ }^{11}$ However, the substantive significance is important to report because there are only 9 women in the study's sample. When it comes to age, 42 percent reported being over the age of 60 . But it appears that age has no effect on their opinion of the creative class (Gamma -.37; $p>.05 ; n=44$ ). ${ }^{12}$ Given how Florida's theory favors educated citizens, it can be assumed that developers with higher levels of education and training are more supportive of creative-class policies than developers with lower education levels. To test this, we examine the respondents' answers on four of the questions in two contingency table analyses. There is no relationship between having completed a training program and opinion on whether organizations marketing their culture opportunities are effective (Gamma $=.06 ; p>.05 ; n=52) .{ }^{13}$ Also, there is no relationship between a developer's education level and their opinion on the effectiveness of promoting culture opportunities (Gamma $=.13 ; p>.05 ; \mathrm{n}=52$ ). ${ }^{14}$ Lastly, there is not a

\footnotetext{
${ }^{8}$ We coded the independent variable as follows: rural $=0$ and urban $=1$. We coded the dependent variable opinion regarding Florida's creative class based on the question: Do you think his ideas would improve economic development in your community ( no $=0$ and yes $=1)$ ?

${ }^{9}$ We coded the independent variable respondents' perception of their work based on their answers to the question: Which one of the following fields best describes your work and educational backgrounds? Public administration = 1 or business administration $=0$. We coded the dependent variable opinion regarding Florida's creative class based on the question: Do you think his ideas would improve economic development in your community (no $=0$ and yes $=1)$ ?

${ }^{10}$ We coded the independent variable respondents' perception of their work based on their answers to the question: Which one of the following fields best describes your work and educational backgrounds? Public administration = 1 or business administration $=0$. We coded the dependent variable marketing cultural capital based on the following scheme: $1=$ not effective at all, $2=$ somewhat effective, 3 = effective, and 4 = very effective.

${ }^{11}$ We coded the independent variable gender as $0=$ men and $1=$ women. We coded the dependent variable opinion regarding Florida's creative class based on the question: Do you think his ideas would improve economic development in your community ( $n$ o $=0$ and yes $=1)$ ?

${ }^{12}$ We coded the independent variable age as follows: $0=18-29$ years, $1=30-44$ years, $2=45-59$ years, and $3=60$ and over. We coded the dependent variable opinion regarding Florida's creative class based on the question: Do you think his ideas would improve economic development in your community ( $n o=0$ and yes $=1)$ ?

${ }^{13}$ We coded the independent variable economic development training based on whether or not the officials stated that they had received training ( $n o=0$ and yes $=1$ ). We coded the dependent variable marketing cultural capital based on the following scheme: 1 = not effective at all, 2 = somewhat effective, 3 = effective, and 4 = very effective.

${ }^{14}$ We coded the independent variable education level based on the following: $0=$ some high school, $1=$ high school graduate, 2 = some college, 3 = Bachelor's degree, 4 = Master's degree, and 6 = Professional degree, i.e., J.D., M.D., or Ph.D. We coded the
} 
statistically significant relationship between a developer's education level and their opinion on whether the creative class theory will help their communities (Gamma $=.23 ; p>.05 ; n=44) .{ }^{15}$

Based on these exploratory analyses, there are no significant differences among the respondents. Education, type of work perception, and demographics has no effect on opinion of the creative class and its development policies. Next, using factor analysis, we explore the commonalities of opinion in our sample.

\subsection{Typology of Opinion: Factor Analysis}

We now return to the study's general hypothesis $\left(H_{1}\right)$ by examining it through factor analysis. As shown in Tables 2 and 3, we asked respondents to rank the efficacy of economic policies for their organizations and communities. To understand the commonalities of opinion among respondents on the effectiveness of these policies, we utilized factor analysis. This methodological tool is used to develop meaningful typology of opinion on specific survey questions (Kim and Mueller, 1978).

The factor analysis of the policies shows that there are three identified factor loadings. ${ }^{16}$ This confirms our assertion that the data does not support $H_{1}$ because there is not one dominant, negative loading of opinion. The practitioners have no overwhelming opinion either for or against the creative class. The three factor loadings are divided along the following types of policies: Factor 1 appears to be related to endogenous policies, Factor 2 appears to be related to exogenous policies, and Factor 3 appears to be related to the creative class policies. It should be clear from Table 5 how we classified the policies into these three types. Factor 1 is by far the largest, explaining 39 percent of the variation. Factor 2 explains 14 percent. And, Factor 3 explains 12 percent. $^{17}$

It is interesting how the respondents' answers group the policies in these three types that represent policies for communities to seek outside firms (exogenous-based policies), grow their current assets (endogenous-based policies), or develop their creativity. These are not mutually exclusive policies, but the clear grouping of positive opinion for traditional policies and negative opinion for creative class policies helps explain distribution of opinion in our sample. It appears that those who favored traditional policies the most were also the most likely to dislike the creative class-related policies. To understand this finding better, we analyzed the qualitative data collected from our survey.

\subsection{Viewpoints of the Creative Class}

Within the survey, we allowed for respondents to leave open-ended comments on a number of the questions. This qualitative data helps explain the quantitative analysis in the previous sections. We asked respondents whether or not Florida's creative class theory would be beneficial to communities with a large manufacturing class. Opinion on this question was split.

dependent variable marketing cultural capital based on the following scheme: 1 = not effective at all, 2 = somewhat effective, $3=$ effective, and 4 = very effective.

${ }^{15}$ We coded the independent variable education level based on the following: $0=$ some high school, 1 = high school graduate, 2 = some college, 3 = Bachelor's degree, 4 = Master's degree, and 6 = Professional degree, i.e., J.D., M.D., or Ph.D. We coded the dependent variable opinion regarding Florida's creative class based on the question: Do you think his ideas would improve economic development in your community (no $=0$ and yes $=1)$ ?

${ }^{16}$ Since we used exploratory factor analysis, a principal component analysis was conducted using varimax rotation. The KaiserMeyer-Olkin (KMO) measure of sampling adequacy is .644, indicating that the sample size is appropriate for factor analysis.

${ }^{17}$ The percentage of variation for each factor is determined by examining the factor's Eigenvalue.

(C) Southern Regional Science Association 2012. 


\section{TABLE 5. Factor Analysis of Opinion on the Efficacy of Development Policies}

\begin{tabular}{l}
\hline $\begin{array}{l}\text { Economic development agencies should focus on attracting } \\
\text { new businesses. }\end{array}$ \\
$\begin{array}{l}\text { Economic development agencies should focus on } \\
\text { improving the current workforce in their communities. }\end{array}$
\end{tabular}

Some of the developers viewed the creative class as a tool to improve a community's quality of life, as exemplified by the following comment: "The arts play a significant role in taking a rural community and moving it into the urban atmosphere. The look and feel of a city with the arts alive and well serves every size area well for growth and happier citizens.”

On the other hand, developers felt that the creative class is not appropriate for all communities, is biased toward certain type of lifestyles, and creates division in communities. This sentiment was best represented in the following comment:

To be frank the concept to me is to provide the wealthy with more exclusive events to attend, that will only serve to further separate them from the working class. Shall we have a glass of wine rather than a County Fair or tractor pull? 
We also asked respondents their opinions on whether or not the creative class ideas would benefit their community. Again, opinion was split with a number of respondents writing insightful comments. The respondents viewing the model as positive focused on how the creative class may be able to attract businesses, as show in the following comments: "Better culturally educated people bring a sense of prosperity to those seeking to bring industry" and "New generations now look for a sense of community in making their career or business location decisions."

The respondents who held a negative opinion on the creative class in their community focused on how the ideas may be in conflict with the area's values and "blue laws" that seek to regulate moral behavior. "Richard Florida's approach is a limited approach that will work well in a few select communities but in should no way be viewed as a "silver bullet" for most communities." "No, artsy people generally like to drink; tough sell in a dry county [a county that does not allow for the sale of alcohol].”

Lastly, we asked respondents to discuss a successful development program that has been implemented in their communities. The comments from this question allows for us to better understand the factor analysis results. Based on these comments, respondents appear to be using the following strategies in their communities: tax incentives, workforce training, tourism promotion, website promotion, and cultural promotion (See, Appendix A).

\section{DISCUSSION}

Kentucky developers hold mixed views about the efficacy of the creative-class theory of economic development. The acceptance of the null for our hypotheses shows that there is no evidence of a bias in favor or against the creative class. In fact, when asked if this model would improve development in their communities, opinion was divided 50:50. The size of our sample $(n=52)$ is a limitation that should be taken into account when interpreting the study's findings. In a research context, the study's findings remain important because the support for the creative class is a contradictory one. It defied our expectations that there would be a bias against the theory. We attempted to explore the causes for this mixed opinion through the use of contingency-table analysis, factor analysis, and analysis of the qualitative data. The results from the contingency tables showed no statistically significant effect on opinion based on the developers' ages, educational backgrounds, advanced training in economic development, work perceptions (i.e., public administration or business administration), gender, and urban vs. rural environments. Factor analysis of the respondents' answers on the efficacy of development policies grouped opinions on three clear types based on exogenous policies, endogenous policies, and creative policies. From this exploratory finding, we conclude that opinion on the economic development tools is heterogeneous in Kentucky.

This finding deviates from expectations regarding the creative class. We hypothesized that rural developers in Kentucky would be highly skeptical of the creative class. We found that rural developers were just as likely to support the theory, as they were to oppose it. A number of urban developers were skeptical of the creative class, which defied our expectations as well. Perhaps recent research on the creative class in rural areas may explain this unexpected finding.

As discussed, McGranahan and Wojan (2007a, 2007b) show that individuals working in the creative class are moving to nonmetropolitan counties, and these communities are enjoying better than average economic growth. Wojan and McGranahan (2007) further argue that 
creative-class movement to rural areas due to amenities may lead to innovative manufacturing growth there. In Figure 4 of this paper, we detailed how creative-class employment is slightly higher in rural Kentucky, compared to the rest of the state. It appears, therefore, that some of the spikes in the creative-class landscape are in rural communities. Perhaps this is why a surprisingly large number of our sampled rural developers support creative-class ideas. Because these officials may agree with McGranahan and Wojan (2007b) that creative-class individuals are moving to rural areas and creative-class development ideas are producing productive rural economies.

The findings deviate partially from Levy's (1990) finding that developers view their work as marketing-related. Tables 2 and 3 showed that marketing-related activities received less support than activities that according to Levy may be better classified as rational model onesfor example, the response on the statement: Economic development agencies should advocate for improvements to the infrastructure (roadways, Internet access, water service, sewerage service, etc.) of their communities. While this finding is not directly related to the study's main focus on perceptions of the creative class, it is an interesting one that is worthy of future research to determine how roles of economic developers in a state like Kentucky may be stuck in an older pattern of behavior. Levy (1990) discussed how the standard view of the roles played by economic developers prior to his survey had been rational model activities. Our expectations were confirmed partially in findings from the factor analysis typology. One group largely supports traditional marketing policies, another group supports business retention and accumulation as the most successful policies, and a third group supports more creative-based policies.

What do these deviations and confirmations mean for economic development practice in the state? The qualitative data in our study may help answer this question. From the developers' open-ended comments, we argue that contextual factors matter for economic development in diverse communities. Respondents, who from their comments appeared to work in cultural capital communities, rural or urban, realized the value of the amenities in development-as one wrote, "The look and feel of a city with the arts alive and well serves every size area well for growth and happier citizens." However, amenities differ from community to community based on many factors from preferences of the population to topography. When it comes to preferences, some communities simply may not enjoy the amenities favored by the creative class. As one respondent bluntly wrote, "Shall we have a glass of wine rather than a County Fair or tractor pull?" The creative-class theory may be one that divides communities with individuals holding this sentiment. Even with this importance of context for development, most parts of the state can find usefulness in certain aspects of the creative class theory.

Accordingly, what aspects of the creative class can bring together the wine drinkers and the tractor pull fans? The answer is in Kentucky's surplus of outdoor amenities. All of the state's regions have strong tourism attractions from the horseraces of the Bluegrass area to Mammoth Cave to the scenic, secluded Appalachian Mountains. As discussed earlier, recent works, in particular McGranahan, Wojan, and Lambert (2010), have shown that rural areas with amenities are attracting significant growth. In these communities, the combined influence of entrepreneurship and creativity is leading to economic success. Development focused on tourism and the attraction of creative classes interested in enjoying outdoor amenities may help communities. The prescription for many communities is to foster tolerance through policies seeking an integration of the creative, service, and manufacturing classes. Such communities in 
many parts of rural Kentucky can take advantage of outdoor amenities to attract new employment based on amenities and use new resources to develop for the future.

To achieve this, McGranahan, Wojan, and Lambert (2010) call for a recasting of the creative class. Rural communities in Kentucky, such as Greensburg and Inez are already implementing their particular models of development with strategies focused on outdoor amenities to strengthen their creative classes. Other communities throughout rural America are also developing their reformulated creative class models. One of these communities is Water Valley, Mississippi, where a small group of creative young professions are reviving this once dead town (Green, 2012). Based on our findings, it can be asserted that there is not strong support for or against the creative class in abstract, but based on a reading of the developers' comments, a recasted model, which relies on rural amenities, may be the appropriate route for many rural communities to grow and retain the creative class.

\section{CONCLUSION}

We surveyed the directors of local economic development agencies in the State of Kentucky to understand their opinion on the efficacy of the creative class and other development policies. Few studies have polled the opinion of local practitioners regarding the creative class theory. In fact, we found no studies in the literature examining the opinion of rural practitioners regarding the creative class. Opinion among the study's developers appears to be heterogeneous, divided along the faults of favoring attraction policies, internal development policies, and tourism promotion (a creative class policy). Our sample of developers appears to be less supportive of the sales activities approach, compared to Levy's (1990) findings. Opinion on the usefulness of the creative class is split.

Rural economic developers were just as likely as urban ones to support the creative-class ideas. We believe this finding to be a significant contribution to the literature. Rural communities are often the ones that can take advantage of outdoor amenities and attract Bohemian creativity (Wojan, Lambert, and McGranahan, 2007). Our findings may show that rural developers, even in a state driven by traditional economic development ideas, may realize the benefits of the creative class for their communities (McGranahan and Wojan, 2007a, 2007b; Rickman and Rickman, 2011). Future research should expand the focus on polling local practitioners to develop future policy prescriptions. This research should be guided by the recent findings (McGranahan, Wojan, and Lambert, 2010; Rickman and Rickman, 2011) concerning the power of outdoor amenities and other creative class attractions in rural communities.

\section{REFERENCES}

Bontje, Marco and Sako Musterd. (2009) "Creative Industries, Creative Class and Competitiveness: Expert Opinions Critically Appraised,” Geoforum, 40, 843-852.

Boschma, Ron A. and Michael Fritsch. (2009) "Creative Class and Regional Growth: Empirical Evidence from Seven European Countries,” Economic Geography, 85, 391-423.

Brock, David M. (2009) “Rural and Remote Canada: Far Out?,” Policy Options. (October) 6979. Retrieved July 27, 2012 from http://www.irpp.org/po/archive/oct09/brock.pdf.

Commerce Lexington. (n.d.) Retrieved February 15, 2012, from http://locateinlexington.com/educate d-workforce.aspx.

(C) Southern Regional Science Association 2012. 
Currid-Halkett, Elizabeth and Kevin Stolarick. (2011) "The Great Divide: Economic Development Theory Versus Practice-A Survey of the Current Landscape,” Economic Development Quarterly, 25, 143 - 157.

Donegan, Mary, Joshua Drucker, Harvey Goldstein, Nichola Lowe, and Emil Malizia. (2008) "Which Indicators Explain Metropolitan Economic Performance Best? Traditional or Creative Class,” Journal of the American Planning Association, 74, 180-195.

Economic Development. (n.d.) Retrieved March 31, 2011, from Create Boston: http://www.createboston.com/.

Economic Growth and ReDevelopment Services Office. (2005) Retrieved March 31, 2011, from City of Austin: http://www.ci.austin.tx.us/redevelopment/.

Florida, Richard. (2003a) The Rise of the Creative Class. New York: Basic Books. . (2003b) “Cities and the Creative Class,” City \& Community, 2, 3-19. . (2009) Who’s Your City? New York: Basic Books. . (2011) The Great Reset. New York: Harper Paperbacks.

Great Streets Initiative. (n.d.) Retrieved March 31, 2011, from Office of the Deputy Mayor for Planning and Economic Development DC. gov:

http://dmped.dc.gov/DC/DMPED/Programs+and+Initiatives/Great+Streets

Giventer, Lawrence L. (2008) Statistical Analysis for Public Administration. Boston: Jones and Bartlett Publishers.

Green, Penelop. (2012) “They Made Main Street Their Own,” New York Times, March 7.

Jacobs, Jane. (1961) The Death and Life of Great American Cities. New York: Vintage Books.

Kentucky League of Cities. (2010) The Basics of Kentucky Cities. Retrieved on September 5, 2011, from http://www.klc.org/UserFiles/TheBasicsNov2010.pdf

Kentucky League of Cities. (n.d.) Greensburg. Retrieved on February 15, 2012, from http://www.klc.org/ccs/detail.asp?itemid=17

Kim, Jae-on and Charles W. Mueller. (1978) Introduction to Factor Analysis: What It Is and How to Do It. Newbury Park, CA: Sage.

Levy, John M. (1990) “What Local Economic Developers Actually Do: Location Quotients Versus Press Release,” Journal of the American Planning Association, 56, 153-160.

Living in Seattle. (n.d.) Retrieved on March 31, 2011, from Seattle.gov: http://seattle.gov/living/

Long, Tad. (2012) Email interview, March 30.

Mathur, Vijay K. (1999) “Human Capital-based Strategy for Regional Economic Development," Economic Development Quarterly, 13, 203-216

McGranahan, David A. and Timothy R. Wojan. (2007a) "Recasting the Creative Class to Examine Growth Processes in Rural and Urban Counties,” Regional Studies, 41, 197216. . (2007b). “The Creative Class: A Key to Rural Growth,” Amber Waves, 5(2), 16-21. 
McGranahan, David A., Timothy R. Wojan, and Dayton M. Lambert. (2010) “The Rural Growth Trifecta: Outdoor Amenities, Creative Class, and Entrepreneurial Context,” Journal of Economic Geography, 11, 529-557.

Neighborhood Revitalization. (2007) Retrieved on March 31, 2011, from the San Francisco Office of Economic and Workforce Development: http://www.oewd.org/NeighborhoodRevitalization-Neighborhood-Marketplace-Initiative.aspx

Peck, Jamie. (2005) “Struggling with the Creative Class,” International Journal of Urban and Regional Research, 29, 740-770

Porter, Stephen R. and Michael E. Whitcomb. (2007) "Mixed-Mode Contacts in Web Surveys: Paper Is Not Necessarily Better,” Public Opinion Quarterly, 71, 4, 635-648.

Pratt, Andy C. (2008) “Creative Cities: The Cultural Industries and the Creative Class," Geografiska Annaler, 90, 107-117.

Putnam, Robert D. (2000) Bowling Alone: The Collapse and Revival of American Community. New York: Simon and Schuster.

Putnam, Robert D. and Lewis M. Feldstein. (2003) Better Together. New York: Simon \& Schuster.

Rausch, Stephen and Cynthia Negrey. (2006) "Does the Creative Engine Run? A Consideration of the Effect of Creative Class on Economic Strength and Growth," Journal of Urban Affairs, 28, 473-489.

Rickman, Dan and Shane D. Rickman. (2011) "Population Growth in High Amenity Nonmetropolitan Areas: What's the Prognosis?,” Journal of Regional Science, 51, 863879.

Romer, Paul M. (1986) “Increasing Returns and Long-Run Growth,” Journal of Political Economy, 94, 1002-1037.

. (1990) “Endogenous Technical Change,” Journal of Political Economy, 98(5), S71S102.

Sands, Gary and Laura A. Reese. (2008) "Cultivating the Creative Class: And What about Nanaimo?” Economic Development Quarterly, 22, 1, 8-13.

Schoales, John. (2006) “Alpha Clusters: Creative Innovation in Local Economies,” Economic Development Quarterly, 20, 2, 162-177.

Schumpeter, Joseph A. (1962) Capitalism, Socialism, and Democracy. New York: Harper Perennial.

Wojan, Timothy R. and David A. McGranahan. (2007) “Ambient Returns: Creative Capital’s Contribution to Local Manufacturing Competitiveness," Agricultural and Resource Economics Review. 36, 133-148.

Wojan, Timothy R., Dayton M. Lambert, and David A. McGranahan. (2007) "Emoting with their Feet: Bohemian Attraction to Creative Milieu,” Journal of Economic Geography, 7, 711736. 


\section{Appendix A}

\begin{tabular}{lll}
\hline SOC & Occupation & Type \\
\hline $11-0000$ & Management occupations & Creative \\
\hline $13-0000$ & Business and financial operations occupations & Creative \\
\hline $15-0000$ & Computer and mathematical science occupations & Creative \\
\hline $17-0000$ & Architecture and engineering occupations & Creative \\
\hline $19-0000$ & Life, physical, and social science occupations & Creative \\
\hline $23-0000$ & Legal occupations & Creative \\
\hline 25-0000 & Education, training, and library occupations & Creative \\
\hline $27-0000$ & Arts, design, entertainment, sports, and media occupations & Creative \\
\hline $29-0000$ & Healthcare practitioners and technical occupations & Creative \\
\hline 21-0000 & Community and social services occupations & Service \\
\hline $31-0000$ & Healthcare support occupations & Service \\
\hline $33-0000$ & Protective service occupations & Service \\
\hline $35-0000$ & Food preparation and serving related occupations & Service \\
\hline $37-0000$ & Building and grounds cleaning and maintenance occupations & Service \\
\hline $39-0000$ & Personal care and service occupations & Service \\
\hline $41-0000$ & Sales and related occupations & Service \\
\hline $43-0000$ & Office and administrative support occupations & Service \\
\hline $47-0000$ & Construction and extraction occupations & Working \\
\hline $49-0000$ & Installation, maintenance, and repair occupations & Working \\
\hline $51-0000$ & Production occupations & Working \\
\hline $53-0000$ & Transportation and material moving occupations & Working \\
\hline Does not include SOC 45-0000 (Farming, Fishing, and Forestry) and 55- & \\
\hline 0000 (Military) & \\
\hline & & \\
\hline
\end{tabular}

(c) Southern Regional Science Association 2012. 